\title{
INNOVATIONS AND COMPETITIVE ADVANTAGE IN PHARMACEUTICAL INDUSTRY IN THE REPUBLIC OF CROATIA
}

\author{
Ivana Kovač \\ Anja Basić**
}

\begin{abstract}
Growing competition and market dynamics are some of the main features of modern economics so resources such as knowledge and human capital are increasingly emerging. The main aim of this paper is to examine the effects and consequences of innovations in pharmaceutical companies in Croatia, their advantages and disadvantages, the importance of innovation as key drivers of the business, problems they encounter when introducing innovations regarding acceptance and adaptation to new changes in the company. For the purpose of data collection, interviews were conducted with representatives of companies that are performing leading functions and therefore they provided insight into the main differences that make these companies stand out among the competition as well as the characteristics of those innovations that make them unique on the market. Interviews were conducted with a small number of companies, which is why generalization can result in a high degree of bias. Nevertheless, insight has been provided into the correlation regarding investment, innovation, and the benefits they provide for the employees, industry, and society. The differences found can serve as a basis for further research and improvement of the current practice within the industry.
\end{abstract}

KEYWORDS: pharmaceutical industry, innovation, competitive advantage, technology transfer

\footnotetext{
*Ivana Kovač, University of Zagreb Faculty of Economics and Business, Croatia; ikovac@ efzg.hr.

**Anja Basić, Bayer Ltd., Croatia; anja.basic2@gmail.com.
} 


\section{INTRODUCTION}

The competitiveness of enterprises must be based on the standards of the global market and the limits of productivity of the most successful enterprises at the world level since the domestic and local markets cannot be protected by isolation mechanisms from competitive pressures that exist beyond borders. It is only through a systematic innovative activity that it is possible to differentiate a product and make it more attractive to customers. ${ }^{1}$ Technology and innovation are some of the key determinants of long-term per capita productivity and growth. In a global economy characterized by growing competition and geographically divided and mobile manufacturing activities, knowledge and innovation are becoming increasingly important sources of sustainable competitive advantage. ${ }^{2}$ The basis of sustainable competitive advantage is invisible resources because invisible resources are specific to the enterprise that owns them, but also because such resources are not easily imitated. ${ }^{3}$ As a result, technological and innovation policies are becoming a major objective of economic policy. Their role is even more prominent thanks to modern processes such as increased global competitiveness and shortening the product life cycle. Investigating the effects and consequences of innovations in pharmaceutical companies operating on the territory of the Republic of Croatia can provide insight into their advantages and disadvantages, the intensity of their importance to innovations as key drivers of the business, the problems they face in introducing innovations in terms of accepting and adapting to new ones, the changes in the company and a reflection of these innovations on the overall business activities. Furthermore, once the difficulties and obstacles have been identified, it is possible in the future to work on how they can be more easily mitigated and brought to the highest productivity point.

\footnotetext{
1 Heraty, N., Morley, M.J.: Management Development in Ireland: The New Organizational Wealth, Journal of Management Development, 22 (1) 2003, pp. 60-82.

2 Nolan A., D. Pilat: Benefitting from the Next Product revolution, OECD Insights, 2016

3 Wong, Y. C., Karia, N.: Explaining the competitive advantage of logistics service providers: A resource-based view approach, International Journal of Production Economics, 128 (1) 2010, pp. 51-67.
} 


\section{THE THEORETICAL FRAMEWORK}

\subsection{INNOVATION AS THE BASIS OF ACTION OF COMPETITIVE ENTERPRISES}

The definitions of innovation are different, but most of them emphasize new approaches or products as a result of significant improvements, including the generation, development, and implementation of new and better ideas regarding production, products, rules, strategies, services, procedures, models and other solutions that create added social and economic value. ${ }^{4}$ The key distinction between the concepts of invention and innovation is crucial. Definitions may differ, but they all share a common point, which is to emphasize the importance of completing development and the practical use of new knowledge, not just invention or invention per se. The invention is only the first step in realizing and implementing a good idea, and in order to become an innovation, it must be molded into the product or service that consumers want and that needs to be commercialized..$^{5}$ On the other hand, innovation is any idea, behavior, or product that is qualitatively different from the existing and previous forms and as such entails the successful conceptualization and marketing of new products or services. ${ }^{6}$ Building a sustainable advantage in a highly competitive environment is a difficult task and may result in the irrational use of already scarce resources. ${ }^{7}$ Competitive advantage ensures the company's financial survival. The basis of sustainable competitive advantage is invisible resources because invisible resources are specific to the enterprise that owns them and because they cannot be easily imitated. ${ }^{8}$ Innovation is the process of generating creative ideas and turning them into useful product, service, or method..$^{9}$ On the other hand, innovation is the process by which companies use

\footnotetext{
4 Crespell, P., Hansen, E.: Managing for innovation: Insights into a successful company, Forest products journal, 58(9) 2008, pp. 6-17.

5 Tidd J., Bessant J.: Managing innovation: Integrating technological, market and organizational change. Chichester: J. Wiley and Son, 2009

6 Cakar, N. D., Erturk, A.: Comparing Innovation Capability of Small and Medium-Sized Enterprises: Examining the Effects of Organizational Culture and Empowerment, Journal of Small Business Management, 48 (3) 2010, pp. 325-359.

7 D'Aveni, D. A.: Beating the Commodity Trap: How to Maximize Your Competitive Position and Increase Your Pricing Power. Boston: Harward Business Press, 2010

8 Wong, Y. C., Karia, N.: Explaining the competitive advantage of logistics service providers: A resource-based view approach, International Journal of Production Economics, 128 (1) 2010, pp. 51-67.

9 Boddy, D.: Management: an introduction. Pearson Education, 2008
} 
their skills and resources to develop new products and services or to develop new production and service systems to better meet customer needs. ${ }^{10}$ Some authors define innovation as key, non-routine, and intermittent organizational changes that embody new ideas that are not in line with the company's current business concept. ${ }^{11}$ With technological breakthroughs and innovations, the emphasis is on technology that is new or improved from previous versions. They may include new products/services, new processes (or enhanced processes). The link between new products/services and new processes is crucial. ${ }^{12}$ It is important to note that technological innovation can create the need for non-technological innovation in the enterprise. Non-technological innovations stimulate and enable the development and introduction of technological innovations, thereby generating higher revenues as well as better utilization of innovation capacities in enterprises. ${ }^{13}$

\subsection{INNOVATIONS AND TECHNOLOGY IN PHARMACEUTICAL INDUSTRY}

Investing in innovation is a prerequisite for achieving much-needed advances in healthcare, as well as in securing the future of the pharmaceutical industry. There was a perception that research and development departments in pharmaceutical companies were no longer innovative and that they were not bringing new drugs or products to the market, and that the market was replete with an increasing number of similar drugs with the same or similar effect that did not show significant progress. Besides, the cost of inventing and developing new drugs (cost per launch) has increased dramatically over the years. ${ }^{14}$ Between 1996 and 2003, there was a downward trend in approved innovation. During this period, many analysts felt that the pharmaceutical industry was significantly less innovative compared to the previous period. The year 1996 is considered to be an exceptional year in which a large number of medicines have been approved, more than in any previous year. Also, during

\footnotetext{
10 Jones, G.R.: Organisational Theory, Design and Change. (5. Ed.), Pearson Hall, 2007

11 Mezias S.J., Glynn, M.A.: The Three Faces of Corporate Renewal: Institution, Revolution and Evolution, Strategic Management Journal, 14 1993, pp. 77-101.

12 Radas, S., Božić, L.: The antecedents of SME innovativeness in an emerging transition economy, Technovation, 29 (6-7) 2009, pp. 438-450.

13 Armbruster, H., Bikfalvi, A., Kinkel, S., Lay, G.: Organizational innovation: The challenge of measuring non-technical innovation in large-scale surveys, Technovation, 28 (10) 2008, pp. 644-657.

14 Schmid, E. F., Smith, D. A.: Is pharmaceutical $R \& D$ just a game of chance or can strategy make a difference?, Drug discovery today, 9 (1) 2004, pp. 18-26.
} 
the first 10 years after World War II, there was a period of growth in which the US pharmaceutical industry showed its dominance. The credit for this growth can also be attributed to the Army's increased need for modern medicines during the war. In the first decade of the 21 st century, a turning point and a turning point in the evolution of the research part of the pharmaceutical and biopharmaceutical industries can be observed. The turnaround is partly the result of key events of the decade, such as the one that happened on 9/11/2001 (WTC attack) and US bioterrorist attack in 2002. ${ }^{15}$ In addition, the emergence of H5N1 (bird flu), H1N1 (swine flu), and SARS flu have led to an increased need for new solutions, innovations, new drugs to prevent possible catastrophic disasters of this type and endangering human lives. ${ }^{16}$ As noted above, the notion of innovation does not necessarily mean marketing a new product, but may also manifest itself by improving marketing access to the market and potential customers. The World Health Organization (WHO) has argued that the use of digitization and digital marketing within healthcare organizations and pharmaceutical companies is of great importance nowadays as it can greatly contribute to the advancement of human health and basic needs.

\section{EMPIRICAL ANALYSIS OF THE INFLUENCE OF INNOVATION ON COMPETITIVENESS OF PHARMACEUTICAL ENTERPRISES IN THE REPUBLIC OF CROATIA}

The empirical research aimed to gain insight and identify the key differences that distinguish pharmaceutical companies from their competition and how much resources and attention is paid to innovation and technology transfer and their direct and indirect impact on business, employees, and the public. After selecting the specific companies that make up the theoretical sample in this case, in-depth interviews had been structured. This empirical research covered pharmaceutical companies in the territory of the Republic of Croatia and collected data in the form of an in-depth interview in order to gain insight into the propensity to invest in development and innovation, and the impact of these same investments on business and employees. The results obtained would help to better understand the impact of innovation on people directly and indirectly in contact with them and provide an objective basis for under-

\footnotetext{
15 Preparedness, B.: Public health security and bioterrorism preparedness and response act of 2002, Public law, 107 (188) 2002, p. 188.

16 Fontana, J. M., Alexander, E., Salvatore, M.: Translational research in infectious disease: current paradigms and challenges ahead, Translational Research, 159 (6) 2012, pp. 430-453.
} 
standing and improving the process of innovation implementation if potential problems encountered during implementation are considered.

\subsection{SAMPLE AND RESEARCH INSTRUMENT}

Respondents who have represented companies have been in the front office for many years. The sample consisted of nine managers/directors. At the beginning of the interview, respondents were guaranteed that confidential company information would remain secret. Interviews were recorded via audio recorders and the elements of the interviews were electronically documented. The length of the interviews depended on the time available to the respondents. In order to protect the anonymity of the employees, companies are encoded with the characters $\mathrm{X} 1, \mathrm{X} 2, \ldots, \mathrm{X} 9$. Interviews with respondents were conducted over 20-days period (first interview on March 28, and final on April 17, 2019). Eight representatives interviewed came from foreign-owned enterprises, while only one respondent came from a company of Croatian origin. The first company tested (X1) is a globally recognized innovation company with a long tradition and key competencies in the fields of health and agriculture. It develops new molecules for use in innovative products and solutions in the advancement of human, animal, and plant health. The essence of business is held by leading positions in growing markets driven by innovation. It employs about 80 people in the Republic of Croatia. As a globally innovative biopharmaceutical company, the second tested company (X2) pays special attention to the discovery, development, and commercialization of innovative medicines in important areas of healthcare, such as cardiovascular/metabolic health care, cancer, respiratory disease, and inflammatory and autoimmune diseases. In 2016, it invested more than \$ 5.9 billion in research and development worldwide, emphasizing its commitment to finding new drugs that could change patients' lives. With over 100 years of experience, the third-party company (X3) is a leading manufacturer, innovator, and supplier of fermented and semi-synthetic active pharmaceutical substances and a world-renowned supplier of Vancomycin and Colistimethate Sodium products. It has increased sales in over 70 countries around the world thanks to innovations and over 500 customers and is continuously developing and expanding its product range to meet the needs and provide the best possible service to patients worldwide, including Croatia. The next company aims to develop new medicines that help patients and provide a better quality of life. The chemical-analytical development of new active substances, the development of galenic formulations, and clinical trials are particularly emphasized, making the fourth company (X4) tested unique in the market, according to representatives. The focal point of the research is the development of innovative drugs in the fields of inflam- 
matory diseases and pain, cardiovascular disease, oncology, and viral diseases. Furthermore, unlike those previously examined, the fifth respondent (X5) dedicates its business to the protection of animal health and is today a global veterinary business dedicated to supporting its customers and their businesses. Thanks to 60 years of experience, it produces quality medicines and vaccines that are on the market worldwide as well as in Croatia. The innovative pharmaceutical company, as well as the X6 company, is based on improving and extending human life. Their medicines are available in over 150 countries worldwide. They provide solutions for oncology patients, cardiovascular, ophthalmic, respiratory, immunological, and neurological problems. The seventh company (X7) lists the production and sale of generic prescription drugs, over-the-counter medicines, and veterinary products as its core business. They focus on developing high quality generic value-added medicines that are marketed under their own trademarks. X8, on the other hand, includes a factory of medicines, nutritional supplements, and cosmetics. Unlike the others mentioned above, it was opened in Vukovar and has three state-of-the-art units: the department for the production of semi-solid preparations - creams, ointments and gels, the department for the production of non-sterile liquid preparations - syrups and liquid food supplements, and the department for the production of solid preparations - tablets and capsules. The last company tested (X9) is a biopharmaceutical innovation company with over 30,000 employees worldwide. They aim to provide new solutions for patients with chronic diseases. The products of this company can be applied in the fields of oncology, virology, immunology, general medicine, and neurology.

\section{INTERPRETATION OF RESULTS}

\subsection{THE KEY INNOVATION}

X1 has created a Student Recruitment Application (Spot-one). The manager states that this has proven to be an excellent option for relieving existing employees, while on the other hand, it provides an opportunity for students of all colleges, who want to earn money, and have obligations at the faculty during classical working hours. Enterprise (X2) cites an important internal innovation as a new tool for working in the commercial sector (a tool for customer segmentation and targeting). With the help of this innovation, customers are classified or divided into groups A, B, and C. The most influential and largest customers are classified in category A, and it is most important for them to maintain frequent contact, visit them frequently and maintain an 
excellent relationship with them. Such customers are about $15 \%$ of the total number of customers. Important customers are also classified in category B, but they are slightly smaller and not so crucial for maintaining the overall business. Customers B account for about $45 \%$ of all customers. The rest of the buyers are buyers $\mathrm{C}$. Their share in the total sales is quite small, but they are important in maintaining the balance, although they are not key to sales as far as the survival of the business is concerned. In addition to the introduction of similar CRM systems, the third tested company, X3, was the most significant innovation in the previous period when it came to the market for vancomycin in the form of an infusion solution that has been stable at room temperature for a full 16 months, as opposed to the previous 12 to 24 hours. A pharmaceutical composition called "Premixed vancomycin injection in a ready-to-use infusion bag" makes it easier to administer an important antibiotic in the treatment of dangerous hospital infections. Company X4 cites the digitalization of marketing as a significant innovation of the previous period because until now, the channels and methods used to promote products and communicate with customers were limited. X5, as an innovator in veterinary medicine, cites a significant change in its business operations by expanding its product range and improving its key veterinary medicine product to date. As a novelty in their company, company X6 cites a revision of a 2015 document that discusses the postulates and principles of working with patient associations. The ambition of this company is to capture the perspective of patients to integrate it into their daily work. According to him, things have been standardized in the business of the company towards the public, but the innovations that bring new therapies to the market have stood out in the previous period. Most prominent from this project was the first migraine prevention drug, CAR-T therapy for the treatment of acute lymphoblastic leukemia, B-cells in children, and for the treatment of diffuse B-size lymphoma in adults, Luxturn for the treatment of children and adults who have lost sight due to inherited distal dystrophies. Company $\mathrm{X} 7$ is the most prominent manufacturer of two innovative generic drugs, namely cancer and pain medicines for musculoskeletal disorders. A key benefit of the drug lies in the development of a dispersible imatinib mesylate tablet. The tablet has an innovative composition that is made according to an independent process patented by this company. Company (X8, as the original Croatian company, has developed a SkinAge product line, which is patented and created to preserve health and beauty and prevent skin aging and comes in the form of a solution, powder, and cream, covering the needs of different types of potential customers. Company X9 cites a project called \#nemapredaha as the largest project they are working on. The X9 project, in collaboration with the Innovative Pharmaceutical Initiative and other participants, was launched to improve the quality of life and cure rates for patients suffering 
from blood cancer, hemophilia, lung cancer, Alzheimer's disease, type 1 diabetes, migraine, and other bacterial infections.

\subsection{BENEFITS AND CHALLENGES OF IMPLEMENTATION}

Enterprise X1 emphasizes the burden on employees and the ability to delegate time-consuming tasks as the biggest asset of this project. On the other hand, it gives students who have a lot of obligations in college during the workweek the opportunity to make money. New employees are hired to work on the said application, working on that application every day and trying to make it as day-to-day as possible. They listed increased costs due to increased workload and hiring of new employees, as well as overtime realized by the existing employees of the company that designed the application. Concerning the perception of the general public about X1, they believe that the company is paying attention to young people and their employment and education, which is certainly a positive element in the corporate image. X2, on the other hand, points out that there were a lot of negative moments when implementing the CRM system in terms of customization and poor comments on the overall situation. They most often came from colleagues of middle or older age because they did not grow up with computers and IT equipment, such as the younger generation, and for them, therefore, this was learning "from scratch". The new system has brought transparency in the performance of tasks and requires an up-to-date update of data, which is a problem for someone who has not worked that way before. Meetings and training were held for both senior and junior colleagues and were supported at all times by colleagues from the IT department. As for the overall impression, he states that the result is certainly better market connectivity and clearer goals, which at one hand has made the job easier and better in the long run. Due to the very nature and working atmosphere of company X3, their innovation, they say, left a distinctly and exclusively positive impression. As the company pays the greatest attention to scientists, their personal and professional satisfaction is such a great breakthrough, and the hard work and effort they put into making this innovation is something they are proud of now. The pursuit of this innovation has provided opportunities and resources for research and development of new medicines in Croatia, and our scientists have once again come to the fore. Besides, with the FDA's approval, the motivation to market new innovative drugs which they are currently working on has increased. This innovation has been a great motivator for the employees to achieve great results in the future, for which they are more than capable. In contrast, the situation is different in $\mathrm{X} 4$. The innovation they implemented caused dissatisfaction with how they functioned differently and, according to the managers, felt that the decision 
was made too soon and went from "nothing" to "everything". The change was not introduced gradually but, as they say, the whole situation was imposed and there was an opinion among the employees that they should be asked if they wanted this change or not. It is predicted that the X4 business could be better, but the adaptation phase, which according to managers, has long seen "worse results" as the focus of employees is on adapting to new technologies rather than customers, which should be the focus. Also, a dose of talent is needed for marketing this type to optimize digitization. Employees felt that this was a bad time to make drastic changes, but were forced to adjust to the situation, even though a case had occurred where the person left the job. In the case of X5, the manager states that they were primarily inclined to think that they were entering new unknowns and felt a great deal of uncertainty about the same, but after a certain period (1+ years) it turned out that they were indeed given new learning opportunities, better positioning of the company. Also, there was, of course, greater security in the company as well as greater opportunities for career advancement. In terms of finance, innovation has resulted in increased profitability and the company has been recognized by the public as an innovator and producer of excellent products. The change and novelty in the case of company X6 have brought several positives to its employees, in addition to the challenges. The document was presented to employees through discussions with patient associations. Employees had the opportunity through real-life stories and conversations to gain insight into how their work has a daily impact and how it will affect human lives and well-being in the future. X6 is best known among patients' organizations in 2018, with 1011 out of 1500 patient groups surveyed claiming to be familiar with X6 and its positive contributions. Besides, this company has become the first company in the world to register CAR-T therapy, which has additionally gained a positive reputation, both in the general and professional public. In addition to the difficulties encountered in inventing and patenting innovations, an X7 representative said that everything was a trifle given the pride felt within the company after its incredible success. He further stated that human resources in their company were the key component and the recipe for success and that without exceptional and motivated employees, such results would not be possible. Inventive and patent-pending product-integrated solutions have enabled this company to successfully launch products. Both innovations bring the most benefit to end-users - patients. The focus was certainly on the highest quality, safety, and better availability. X7 has received numerous awards for the above two inventions. X8, on the other hand, as the original Croatian company with a small number of employees, states that they are also extremely proud of the success associated with this innovation, but also of all innovations that make one's life easier and better. Besides, for the product from the SkinAge line, they won 
the Cosmopolitan Beauty Award for 2018 as one of the best innovations in the beauty industry. X9 company says the process is challenging in itself because the campaign launched raises high expectations from the public and the issue is related to an extremely sensitive area. As for the employees themselves, participating in such projects is a very emotional and physically difficult process, and they must be encouraged and motivated daily. As a company, they say, there is a long and difficult road ahead, a large number of overtime hours and numerous meetings that addressed the problems they encountered along the way. It further states that around 8,000 people in Europe have hemophilia B, $60 \%$ of whom live with a severe form of the disease. Therapy in the studies has shown sufficient results to transform the disease into a milder form. Over time, other forms of therapy, such as cancer and infections, could be addressed through such forms of therapy, making an immense contribution to society and making life easier for those who need it most.

\subsection{RESEARCH AND DEVELOPMENT}

Regardless of the innovations implemented and the benefits that these innovations have brought, none of the companies tested, except X3 and X8, has an R\&D department in Croatia. The manager of X2 points out that there is certainly more investment in R\&D in other countries, as these countries are always in greater focus both in development and in financial terms. The market is bigger, the potential is higher, and more funds go directly to those markets. He also states that regulations vary from country to country, as well as the amount of money spent at faculties for laboratory and clinical research and in youth and science development. In his view, these prospects are still low in Croatia, despite the fact that we have great potential. Other companies generally have global R\&D departments and are therefore unable to provide data. $\mathrm{X} 3$, on the other hand, has a research and development department in Croatia and employs as many as 80 scientists of various profiles in the fields of biomedical, natural, and biotechnical sciences, mostly educated at Croatian universities. The director states that there are other locations and countries where R\&D is performed for the company, but believes that there is no significant difference in focus, even on the contrary, R\&D in Croatia is increasing year by year due to the competence of the researchers. In addition, it states that the share of R\&D expenses in the company's revenue is about 10\%. The overview of key items of in-depth interviews can be seen in table 1 . 


\section{Table 1. Overview of key items of in-depth interviews}

\begin{tabular}{|c|c|c|c|c|c|c|}
\hline $\begin{array}{l}\text { C } \\
0 \\
\text { M } \\
\text { P } \\
\text { A } \\
\text { N } \\
\text { Y }\end{array}$ & $\begin{array}{l}\text { INNOVATION } \\
\text { THAT STANDS } \\
\text { OUT THE MOST }\end{array}$ & $\begin{array}{l}\text { IMPACT OF } \\
\text { INNOVATION ON } \\
\text { EMPLOYEES }\end{array}$ & $\begin{array}{l}\text { IMPACT OF } \\
\text { INNOVATION } \\
\text { ON BUSINESS } \\
\text { AND PUBLIC } \\
\text { PERCEPTION }\end{array}$ & $\begin{array}{c}\text { CHALLENGES } \\
\text { DURING } \\
\text { IMPLEMENTATION }\end{array}$ & $\begin{array}{c}\text { R\&D } \\
\text { DEPARTMENT } \\
\text { AND } \\
\text { NUMBER OF } \\
\text { EMPLOYEES } \\
\text { IN CROATIA }\end{array}$ & $\begin{array}{c}\% \text { OF } \\
\text { COSTS } \\
\text { OF } \\
\text { R\&D IN } \\
\text { TOTAL } \\
\text { INCOME } \\
(\%)\end{array}$ \\
\hline X1 & $\begin{array}{l}\text { Spot-one platform } \\
\text { for student } \\
\text { employments }\end{array}$ & $\begin{array}{l}\text { Possibility for } \\
\text { delegating jobs and } \\
\text { decrease pressure. }\end{array}$ & $\begin{array}{l}\text { Positive impact on } \\
\text { student wellbeing. }\end{array}$ & $\begin{array}{l}\text { More work, long } \\
\text { work hours. }\end{array}$ & NO & 1 \\
\hline $\mathrm{X} 2$ & $\begin{array}{l}\text { Tool for working in } \\
\text { commercial sector } \\
\text { (segmentation } \\
\text { and targeting of } \\
\text { customers). }\end{array}$ & $\begin{array}{l}\text { In the beginning } \\
\text { difficult adaptation } \\
\text { due to new systems. } \\
\text { After adaptation, } \\
\text { efficiency } \\
\text { improved. }\end{array}$ & $\begin{array}{l}\text { Positive } \\
\text { impact. Better } \\
\text { communication } \\
\text { with clients. }\end{array}$ & $\begin{array}{l}\text { Additional } \\
\text { educations and } \\
\text { support was needed. } \\
\text { Slow adaptation of } \\
\text { employees. }\end{array}$ & NO & 1 \\
\hline X3 & $\begin{array}{l}\text { Vancomycin } \\
\text { Injection as a } \\
\text { premixed solution } \\
\text { in stable at room } \\
\text { temperature for } 16 \\
\text { months. }\end{array}$ & $\begin{array}{l}\text { Extremely } \\
\text { positive impact } \\
\text { on employees. } \\
\text { Success represents } \\
\text { additional } \\
\text { motivation. } \\
\end{array}$ & $\begin{array}{l}\text { Extremely positive } \\
\text { due to big impact } \\
\text { on improved } \\
\text { treatment of } \\
\text { patients and general } \\
\text { health. }\end{array}$ & $\begin{array}{l}\text { Very few obstacles, } \\
\text { big motivation and } \\
\text { dedication. }\end{array}$ & $\begin{array}{l}\text { YES, } 80 \\
\text { employees }\end{array}$ & 1 \\
\hline X4 & $\begin{array}{l}\text { Digitalization of } \\
\text { marketing }\end{array}$ & $\begin{array}{l}\text { Resistance of } \\
\text { employees due to } \\
\text { lack of information } \\
\text { about project } \\
\text { and reluctance to } \\
\text { change }\end{array}$ & $\begin{array}{l}\text { Positive and } \\
\text { negative. } \\
\text { Neglecting current } \\
\text { business because of } \\
\text { difficult adaptation. } \\
\text { Marketing, on } \\
\text { the other hand, } \\
\text { improved. }\end{array}$ & $\begin{array}{l}\text { Lots of seminars and } \\
\text { education. Lack of } \\
\text { motivation among } \\
\text { employees and } \\
\text { resistance. }\end{array}$ & YES & 1 \\
\hline X5 & $\begin{array}{l}\text { Expanding product } \\
\text { assortment and } \\
\text { improvement of } \\
\text { „old product" }\end{array}$ & $\begin{array}{l}\text { Overtime work } \\
\text { and more space } \\
\text { for promotions, } \\
\text { challenges and } \\
\text { progress inside the } \\
\text { company. }\end{array}$ & $\begin{array}{l}\text { Positive due to } \\
\text { improved product } \\
\text { according to } \\
\text { customer's needs. }\end{array}$ & $\begin{array}{l}\text { Long workhours, } \\
\text { additional } \\
\text { workshops and } \\
\text { trainings. }\end{array}$ & NO & 1 \\
\hline X6 & $\begin{array}{l}\text { Revising the } \\
\text { document on } \\
\text { postulates and } \\
\text { principles about } \\
\text { working with } \\
\text { patient associations }\end{array}$ & $\begin{array}{l}\text { Opportunity for } \\
\text { employees to } \\
\text { get first-hand } \\
\text { impression through } \\
\text { conversation with } \\
\text { patients. }\end{array}$ & $\begin{array}{l}\text { Positive public } \\
\text { perception, } \\
\text { especially from } \\
\text { patients' side, } \\
\text { due to personal } \\
\text { approach. }\end{array}$ & $\begin{array}{l}\text { Educations and } \\
\text { adaptation to } \\
\text { new ways of } \\
\text { communication. }\end{array}$ & NO & 1 \\
\hline X7 & $\begin{array}{l}\text { Invention of two } \\
\text { innovative generics. }\end{array}$ & $\begin{array}{l}\text { Dedication to } \\
\text { the project and } \\
\text { additional overtime } \\
\text { work is needed. }\end{array}$ & $\begin{array}{l}\text { Positive, since the } \\
\text { new approach in } \\
\text { treating patients is } \\
\text { available now. }\end{array}$ & $\begin{array}{l}\text { Lots of challenges, } \\
\text { but overcame with } \\
\text { teamwork and } \\
\text { positive spirit. }\end{array}$ & NO & 1 \\
\hline X8 & $\begin{array}{l}\text { SkinAge product } \\
\text { line }\end{array}$ & $\begin{array}{l}\text { Hard work of } \\
\text { employees, that } \\
\text { provided good } \\
\text { results. }\end{array}$ & $\begin{array}{l}\text { Positive, due to } \\
\text { huge success of } \\
\text { domestic brand. }\end{array}$ & $\begin{array}{l}\text { Different obstacles } \\
\text { during market } \\
\text { placement. }\end{array}$ & $\begin{array}{l}\text { YES, number is } \\
\text { a secret. }\end{array}$ & 1 \\
\hline X9 & $\begin{array}{l}\text { Active contributing } \\
\text { in campaign } \\
\text { \#WeWontRest }\end{array}$ & $\begin{array}{l}\text { Challenging work } \\
\text { for employees due } \\
\text { to sensitive topic } \\
\text { and great promises }\end{array}$ & $\begin{array}{l}\text { Big expectations } \\
\text { but positive impact } \\
\text { due to improved } \\
\text { wellbeing of } \\
\text { patients. }\end{array}$ & $\begin{array}{l}\text { Obstacles during } \\
\text { product placement, } \\
\text { additional } \\
\text { explanations } \\
\text { regarding therapy } \\
\text { needed. }\end{array}$ & NO & 1 \\
\hline
\end{tabular}




\section{LIMITATIONS OF RESEARCH}

The limitations of this research stem primarily from the definition of the sample. Interviews were conducted with a small number of companies and for this reason, generalization can result in a high degree of bias. However, the data obtained can provide a reflection of the pharmaceutical companies' attitudes towards investments and the potential benefits for the employees in the context of the labor market and the economic situation in the Republic of Croatia. Also, data can serve as a starting point for further analysis and as a good benchmark for starting other research on a similar topic. Some of the information collected through the interviews is considered a trade secret and as such could not be presented in the research results, although it contributes to a better understanding of the competitive advantage of the company. In order to increase the significance of the research results, the sample should include a larger number of enterprises within the industry.

\section{CONCLUSION}

The most important resource, or source of competitive advantage, in addition to these innovation projects, is human resources. Employees are considered a valuable resource, which can contribute to the profitability and success of the business and to the positive reputation of the company. Most companies, when implementing innovation, invest in education, training, and additional training for their employees. One of the companies, due to the inability to properly manage and accept the change, states that an employee has left the workplace. It is of utmost importance that the employees have a sufficient amount of support from the company as well as the opportunity to participate actively in the process. In addition to human capital as a source of competitive advantage in the company, it is crucial to introduce timely innovation and invest in R\&D. At the level of the Republic of Croatia, as can be deduced from the research, only two of the nine companies surveyed have an R\&D department in the territory of the country, while other companies, due to the small market and insufficient financial and development focus, implement the innovations modeled after the research conducted in other countries. Furthermore, by talking to business representatives, one could get the impression that countries with head offices outside Croatia are of the opinion that the competencies of scientific staff abroad are at a higher level and that it is, therefore, more cost-effective to invest in research and development and scientists, not in the territory of Croatia or the Balkans. However, one of the companies with an R\&D department in Croatia proves the opposite. Over 80 exceptional and talented employees of the Research Laboratory in Zagreb achieve exceptional results 
and are grateful to the managers of their company for the recognized potential and invested resources that enable not only the company to be competitive and profitable but also to young scientists who achieve exceptional results to study and participate in numerous research, to gain employment opportunities in the profession and build on their talent bringing it to a high level. The company as such is a positive example that enables young educated people to stay in the Republic of Croatia after completing their university education, without the need to seek better opportunities to study abroad.

\section{LITERATURE}

1. Armbruster, H., Bikfalvi, A., Kinkel, S., Lay, G.: Organizational innovation: The challenge of measuring non-technical innovation in large-scale surveys, Technovation, 28 (10) 2008, pp. 644-657.

- DOI: https://doi.org/10.1016/j.technovation.2008.03.003

2. Boddy, D.: Management: an introduction. Pearson Education, 2008.

3. Cakar, N. D., Erturk, A.: Comparing Innovation Capability of Small and Medium-Sized Enterprises: Examining the Effects of Organizational Culture and Empowerment, Journal of Small Business Management, 48 (3) 2010, pp. 325-359. - DOI: https://doi.org/10.1111/j.1540-627X.2010.00297.x

4. Crespell, P., Hansen, E.: Managing for innovation: Insights into a successful company, Forest products journal, 58(9) 2008, pp. 6-17.

5. D'Aveni, D. A.: Beating the Commodity Trap: How to Maximize Your Competitive Position and Increase Your Pricing Power. Boston: Harward Business Press, 2010.

6. Fontana, J. M., Alexander, E., Salvatore, M.: Translational research in infectious disease: current paradigms and challenges ahead, Translational Research, 159 (6) 2012, pp. 430-453.

- DOI: https://doi.org/10.1016/j.trsl.2011.12.009

7. Heraty, N., Morley, M.J.: Management Development in Ireland: The New Organizational Wealth, Journal of Management Development, 22 (1) 2003, pp. 60-82.

- DOI: https://doi.org/10.1108/02621710310454860

8. Jones, G.R.: Organisational Theory, Design and Change. (5. Ed.), Pearson Hall, 2007.

9. Mezias S.J., Glynn, M.A.: The Three Faces of Corporate Renewal: Institution, Revolution and Evolution, Strategic Management Journal, 14 1993, pp. 77-101.

- DOI: https://doi.org/10.1002/smj.4250140202

10. Nolan A., D. Pilat: Benefitting from the Next Product revolution, OECD Insights, 2016. 
11. Preparedness, B.: Public health security and bioterrorism preparedness and response act of 2002, Public law, 107 (188) 2002, p. 188.

12. Radas, S., Božić, L.: The antecedents of SME innovativeness in an emerging transition economy, Technovation, 29 (6-7) 2009, pp. 438-450.

- DOI: https://doi.org/10.1016/j.technovation.2008.12.002

13. Schmid, E. F., Smith, D. A.: Is pharmaceutical R\&D just a game of chance or can strategy make a difference?, Drug discovery today, 9 (1) 2004, pp. 18-26.

- DOI: https://doi.org/10.1016/S1359-6446(04)02951-4

14. Tidd J., Bessant J.: Managing innovation: Integrating technological, market and organizational change. Chichester: J. Wiley and Son, 2009.

15. Wong, Y. C., Karia, N.: Explaining the competitive advantage of logistics service providers: A resource-based view approach, International Journal of Production Economics, 128 (1) 2010, pp. 51-67.

- DOI: https://doi.org/10.1016/j.ijpe.2009.08.026 
